\title{
THE RELATIONSHIP OF THE VALUE OF MONTHLY PAY MONEY TO THE MOTIVATION OF LEARNING FIKH ON SANTRI AL-HIDAYAH ISLAMIC BOARDING SCHOOL PURWAKARTA
}

\author{
By \\ Imam Tabroni ${ }^{1}$, Rizkiyah Rihhadal Aisy ${ }^{2}$ \\ ${ }^{1}$ Faculty of Islamic Education postgraduate program, STAI Dr. KH. EZ. Muttaqien Purwakarta \\ ${ }^{2}$ Faculty of Islamic Education STAI Dr. KH. EZ. Muttaqien Purwakarta \\ Email: 1imamtabroni70@gmail.com
}

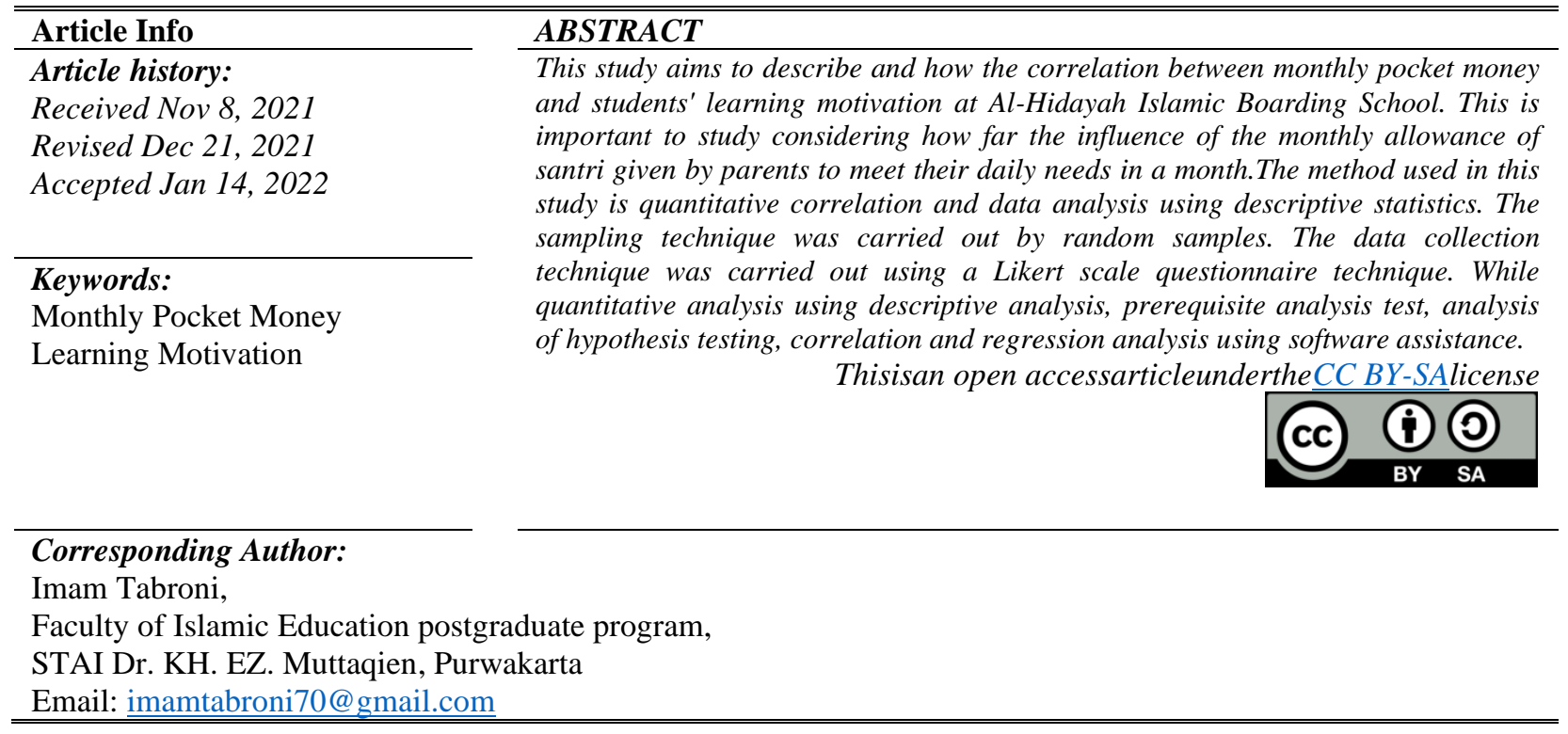

\section{INTRODUCTION}

Pocket money is the contribution of parents to their children with the aim of being able to meet their needs at the cottage, whether it is for consumption needs, dues which are usually unknown to parents, as well as children's infaq needs while at the cottage. In this case, it is clear that pocket money is enough to be a benchmark for supporting their learning process at the cottage. If the child does not get pocket money, various symptoms of problems will arise, such as not being focused and even from one problem, other problems can arise such as lack of socialization, inferiority and which can impact on their achievement. Another factor that is in the spotlight is environmental factors. Whether it's a family, community or cottage environment, this can be seen in terms of the economy, personality, habits, culture, and social strata that usually apply in everyday life. Based on research conducted by Soedarwani by raising the issue of "The Influence of Behavioristic Guidance Model, Learning Motivation and Parent's Economic Level on Discipline of SMA Batik 2 Surakarta Students" by Soedarwani, found some facts about students who can also improve their learning discipline because their needs have been fulfilled by parents).[1]

Dian Ika Puspita Sari, in her journal entitled “Tips for Career Women in Disciplining Children to Manage Pocket Money in Wonorejo Housing, Kedungjajang District, Lumajang Regency" stated that pocket money is money that is not the same as pocket money. Pocket money is used for snacks, saving and donating.[2] The pocket money given by parents to children actually aims to meet all the needs of children related to meeting school needs such as paying for public transportation, buying snacks, paying dues, buying stationery, and others. There are several kinds of functions of pocket money categorized by Bambang Widjajanta, there are: medium of exchange, unit of account, value store tool, and future payment standards.[3]

According to Paul W. Lermitte[4], argues that there are several principles of pocket money, including the following: 
1) Promise to Your Children

Explain to your child that an allowance is an amount of money given out on a daily or weekly basis that allows them to pay for the things that are important to them. Before starting this allowance system promise your child a certain amount of money on a certain day each week give the money that you think is appropriate.

2) Ask Your Child to Promise You

Before the child receives pocket money, suggest promising two things, one he will save some of his pocket money for savings. The remaining two would be used for fun and he wouldn't whine for more money when his allowance was up.

3) Be Consistent and Firm

Once you start giving your child an allowance, try to be consistent and give the promised amount. If he spends his pocket money right away let him know that he has to wait until the next day of pocket money.

4) Don't Associate Pocket Money With Tasks or Achievements

A child should receive an allowance because he is part of the family. Do not use pocket money as a bribe or gift give pocket money to teach your children the basics of good financial management.

5) Make Savings Part of the Contract Pocket Money

Saving money is a habit that must be learned from an early age. Require your child to save $25 \%$ of his pocket money every week and save it in a bank or piggy bank.

Azmi Agustiar revealed that pesantren is an Islamic educational institution that has its own position in the Muslim community and its existence has raised public education to better understand Islamic teachings, where during the Dutch colonial war, Islamic boarding schools were used as places for jihad to defend Allah's religion.[5] Various kinds of reforms increasingly emerged in the 70's, so that this Islamic educational institution has a new term in its name, including modern Islamic boarding schools, integrated Islamic boarding schools, or other terms. This proves that Islamic boarding schools have begun to respond to current world situations and conditions.[6]

Aldila Septiana in her journal entitled "The Madura Islamic Boarding School Financial Literacy Model" in her research stated that giving pocket money to students is the same as society in general, the needs of students vary. So that diverse needs provide many changes. These changes can have a positive or negative effect. Positive influence can be seen in the existence of financial independence. Meanwhile, this negative effect is closely related to the selected consumption expenditure. Some students sometimes force themselves to buy goods or services that are beyond their capabilities. What is meant by being beyond their ability is to buy goods or services beyond the pocket money sent by their parents.[7]

Santri are in transition from dependence to financial independence and must make plans that will affect their welfare and success in the future. The transition period here means that students usually live together with their families without having to think about financial independence. Living apart from family must adapt in Islamic boarding schools where to study for prosperity and success in the future. Sometimes when they are at the beginning of the month (early receiving pocket money from their parents), it is easy for students to spend their money. Meanwhile, if it is at the end of the month (the pocket money supply is running low), the students must be nimble in managing their financial patterns.

According to Sardiman[8], motivation are divided into two, namely:

1) Intrinsic Motivation

What is meant by intrinsic motivation is that motives that become active or function do not need to be stimulated from outside, because every individual has an urge to do something. Students are motivated to learn solely to master the values contained in the learning material, not because of other desires such as wanting to get praise, high grades or prizes and so on.If a person already has intrinsic motivation within himself, then he will consciously carry out an activity that does not require motivation from outside himself. In learning activities, intrinsic motivation is needed, especially self-study. Someone who does not have intrinsic motivation is very difficult to carry out continuous learning activities. Someone who has intrinsic motivation always wants to progress in learning.

2) Extrinsic Motivation

According to Sardiman, extrinsic motivation is the opposite of intrinsic motivation. Extrinsic motivation are motives that will be active and function because of external stimuli.

Extrinsic motivation does not mean unnecessary and not good motivation in education. Extrinsic motivation is needed so that students want to learn. Various ways can be done so that students are motivated to learn. Teachers who teach successfully are teachers who are good at arousing students' interest in learning, by utilizing the extrinsic motivation of students' interest in learning, by utilizing extrinsic motivation in various forms. Misuse of forms of extrinsic motivation will harm students. As a result, extrinsic motivation does not 
International Journal of Social Science (IJSS)

Vol.1 Issue.5 February 2022, pp: 541-548

ISSN: 2798-3463 (Printed) | 2798-4079 (Online)

DOI: https://doi.org/10.53625/ijss.v1i5.869

function as a driver, but makes students lazy to learn. According to Syaiful Bahri Djamarah [9], the forms of motivation in learning are as follows:

a) Giving Numbers

The number in question is a symbol or value from the results of students' learning activities. Good numbers or grades have great potential to motivate students to study harder. Numbers are a motivational tool that is sufficient to stimulate students to maintain or even further improve their learning achievement in the future.

b) Present

A gift is giving something to someone else as an appreciation or memento or souvenir. Prizes can be in the form of scholarships, notebooks, pencils, or other reading books.

c) Competition

Competition is competition, it can be used as a motivational tool to encourage students to be passionate about learning. Competition both in the form of individuals and groups is needed in education. This condition can be used to make the teaching and learning interaction process conducive.

d) Ego-Involment

Raising awareness in students to feel the importance of the task and accept it as a challenge so that they work hard by risking self-esteem, is a very important form of motivation. A person will try with all his strength to achieve good performance by maintaining self-esteem. Likewise with students as learning subjects.

e) Giving Repeat

Repetition can be used as a motivational tool. Students usually prepare themselves by studying ahead of time to face the test. Various efforts were taken in order to be able to master all the learning materials so that it would be easier for them to answer every question posed by the teacher.

f) Knowing Results

By knowing the results, students are encouraged to study harder. Especially if learning outcomes are progressing, students tend to try to maintain the intensity of their learning in order to get better learning achievements in the next semester.

g) Praise

Praise spoken at the right time can be used as a motivational tool. Praise is a positive form of reinforcement and at the same time a good motivation. Teachers can forgive praise for praising students' success in doing work at school. Praise is given according to the work, not made up or at all challenging with the work of students.

h) Punishment

Punishment is a negative reinforcement, but if done properly and wisely is a good and effective motivational tool. Punishment is a motivational tool if it is carried out with an educational approach, not out of revenge. The educational approach referred to here is a punishment that educates and aims to improve the attitudes and actions of students who are considered wrong so that with the punishment given, students do not repeat mistakes and violations. At least reduce the frequency of violations, but it is better if students stop doing it in the future.

i) Desire to Learn

The desire to learn means that there is an element of intentionality, there is an intention to learn. This will be better when compared to all activities without purpose. The desire to learn means that students do have motivation to learn, so of course the results will be better than other students who have no desire to learn. The desire to learn is a potential that is available in students.

j) Interest

Interest is a persistent tendency to pay attention to and remember some activities. Someone who is interested in an activity will pay attention to that activity consistently with pleasure.

k) Recognized Goals

The formulation of goals that are recognized and accepted by students is a very important motivational tool. 


\section{RESEARCH METHOD}

The approach in this study uses a quantitative approach. Quantitative research is a research method based on the philosophy of positivism used to examine certain populations or samples, sampling techniques are generally carried out randomly, data collection uses research instruments, data analysis is quantitative or statistical with the aim of testing predetermined hypotheses.[10] While the method in this study uses the correlative method, the correlative method is the relationship between two or more variables. This study was conducted to determine the correlation between two variables, namely the relationship between monthly allowances and students' learning motivation. Thus, this study seeks to obtain accurate data on how the monthly allowance relates to the motivation to learn fiqh learning in students at the Al-Hidayah Islamic Boarding School.

The population of this study was the seventh grade students of SMP Al-Hidayah, with a population of 30 students. As for the number of samples to be taken, the researcher based on the opinion of Suharsimi Arikunto which stated that, "If the research subjects are less than 100 people, it is better to take all of them, so that the research is a population"[11]. However, if there are more than 100 subjects, it is allowed to take $10 \%-15 \%$ and $20 \%-25 \%$ or more samples.

The data collection technique used in this research is using a questionnaire and interviews. Questionnaire which aims to measure the level of student learning motivation given to all 30 samples using a questionnaire sheet. While the interview aims to find out more about the problem under study with sources from the results of interviews with teachers or caregivers of Islamic boarding schools. The questionnaire used is a closed questionnaire where the research subject is only allowed to choose the answers that have been provided by the researcher. The measurement scale in this research questionnaire uses a Likert scale. The following is a questionnaire assessment criteria based on a Likert scale.

Table 1. Questionnaire Scoring

\begin{tabular}{|c|l|c|}
\hline No & \multicolumn{1}{|c|}{ Category } & Score \\
\hline 1 & Strongly Agree (SS) & 4 \\
\hline 2 & Agree (S) & 3 \\
\hline 3 & Disagree (TS) & 2 \\
\hline 4 & Strongly Disagree (STS) & 1 \\
\hline
\end{tabular}

This research instrument is a tool that is selected and used by researchers in activities to collect data so that activities become systematic and facilitated by them. The instruments used in this research are questionnaires and interviews. The instrument of this research is attached. However, before being used, the instrument was first tested to determine the level of validity and reliability. Research results are valid if there are similarities between the data collected and the data that actually occurs in the object under study. Meanwhile, a reliable instrument is an instrument which, when used several times to measure the same object, will produce the same data.

In conducting the research, the researcher first compiled a grid of research instruments. These grids are used to compose statements that will be given by the researcher to the respondents. The lattice of instrument variables $\mathrm{X}$ and $\mathrm{Y}$ are as follows:

Tabel 2. Monthly Pocket Money Value Questionnaire

\begin{tabular}{|c|c|l|c|c|c|}
\hline \multirow{2}{*}{ No } & \multirow{2}{*}{ Variable } & \multicolumn{1}{|c|}{ Indicator } & \multicolumn{2}{|c|}{ Items } & \multirow{2}{*}{ Totals } \\
\cline { 1 - 3 } 1. & $\begin{array}{c}\text { Pocket money } \\
(\mathrm{X})\end{array}$ & $\begin{array}{l}\text { Ability to save monthly pocket } \\
\text { money }\end{array}$ & 1.2 & 3.4 & 4 \\
\cline { 4 - 5 } & & $\begin{array}{l}\text { Pocket money is associated with } \\
\text { tasks or achievements }\end{array}$ & 5.6 & 7.8 & 4 \\
\cline { 4 - 5 } 3. & $\begin{array}{l}\text { Provision of nominal pocket } \\
\text { money according to age and } \\
\text { needs }\end{array}$ & 9.10 & 11.12 & 4 \\
\hline
\end{tabular}


International Journal of Social Science (IJSS)

Vol.1 Issue.5 February 2022, pp: 541-548

ISSN: 2798-3463 (Printed) | 2798-4079 (Online)

\begin{tabular}{|l|l|l|c|c|c|}
\hline 4. & $\begin{array}{l}\text { The amount of pocket money is } \\
\text { measured from the distance from } \\
\text { the school to the house }\end{array}$ & 13.14 & 15,16 & 4 \\
\cline { 3 - 6 } 5. & $\begin{array}{l}\text { Amount of pocket money in a } \\
\text { month }\end{array}$ & 17.18 & 19,20 & 4 \\
\hline
\end{tabular}

Tabel 3. Learning Motivation Questionnaire Grid

\begin{tabular}{|c|c|c|c|c|c|}
\hline \multirow{2}{*}{ No } & \multirow{2}{*}{ Variable } & \multirow{2}{*}{ Indicator } & \multicolumn{2}{|c|}{ Items } & \multirow{2}{*}{ Totals } \\
\hline & & & + & - & \\
\hline 1. & \multirow{5}{*}{$\begin{array}{c}\text { Motivation to } \\
\text { learn } \\
\text { (Y) }\end{array}$} & Shows interest in various problems. & 1.2 & 3.4 & 4 \\
\hline 2. & & Have the drive to achieve something. & 5.6 & 7.8 & 4 \\
\hline 3. & & Committed to learning. & 9.10 & 11.12 & 4 \\
\hline 4. & & $\begin{array}{l}\text { Internal factors that affect learning } \\
\text { motivation. }\end{array}$ & 13.14 & 15,16 & 4 \\
\hline 5. & & $\begin{array}{l}\text { External factors that affect learning } \\
\text { motivation. }\end{array}$ & 17.18 & 19,20 & 4 \\
\hline
\end{tabular}

Data analysis is an activity after data from all respondents or other data sources are collected. Activities in data analysis are grouping data based on variables and types of respondents, tabulating data based on variables from all respondents, presenting data for each variable from all respondents, presenting data for each variable studied, performing calculations to answer the problem formulation and performing calculations to test hypotheses that have been developed. submitted. Data analysis techniques in quantitative research use statistics. The analytical technique is one of the steps used in research activities which is very important in determining the accuracy and validity of research results.

\section{RESULTS AND ANALYSIS}

\subsection{Description of Data For Each Variable}

Based on the results of the percentage data to determine the variable X, namely the amount of pocket money with an average value of $82.83 \%$ of all statements. Referring to the percentage and scoring criteria, the figure is in the interval $82.00-100.00$ very well. Thus, this shows that the average monthly allowance of respondents is very good, which means that students always get their pocket money every month with different amounts. With the results of the criteria being very good, students are able to manage money well. Meanwhile, the Y variable is learning motivation with an average value of $91.88 \%$ of all statements. Referring to the percentage and scoring criteria, the figure is in the interval $82.00-100.00$ very well. Thus, it shows that the average respondent's motivation to learn is very good, which means that students have a high enough motivation in learning which is contrary to the field results which show differences during the teaching and learning process.

Pocket money according to Entika defines that pocket money is a form of developing responsibility, so it needs to be accompanied by instilling value in children so that pocket money can be used properly. This is supported by the theory put forward by Bambang Widjajant that one of the functions of pocket money is as a store of value associated with the ability to save money from transactions or gifts that increase purchasing power so that all transactions do not need to be spent on the spot. . Pocket money has a principle as proposed by Paul W. Lermitte, one of which is to be consistent and firm, which means to give the promised amount of pocket money, if he 
immediately spends the allotted money, the consequence is that he has to wait until the day he is paid. pocket money the next day.

Students who are able to take advantage of the monthly allowance with the rules imposed by the boarding school administrator will certainly find it easier and understand the meaning of using the pocket money they have received from their parents every month. If this is done regularly and earnestly by students, it is possible that students will be smart and accustomed to managing finances so that pocket money is not an excuse to increase learning motivation.

\subsection{Research Hypothesis Testing}

The main hypotheses in this study are:

a) Alternative hypothesis (Ha): there is a relationship between variable $\mathrm{X}$ (monthly allowance) and variable $\mathrm{Y}$ (learning motivation).

b) The null hypothesis (Ho): there is no relationship between the variable $\mathrm{X}$ (monthly allowance) and the variable $\mathrm{Y}$ (learning motivation).

To answer the hypothesis, correlation statistic test was conducted. Correlation shows the strength of the linear relationship and the direction of the relationship between two variables. If the correlation is positive, then the two variables have a unidirectional relationship. That is, if the value of variable $\mathrm{X}$ (monthly allowance) is high, then the value of variable Y (motivation to learn) will also be high. Conversely, if the correlation value is negative, then the value of the variable $\mathrm{X}$ (monthly allowance) is low, then the value of the variable $\mathrm{Y}$ (learning motivation) is low and vice versa. The correlation coefficient test with computer tools, as follows:

Tabel 4. Correlation Calculation Output

\begin{tabular}{|l|l|r|r|}
\hline \multicolumn{4}{|c|}{ Correlations } \\
\hline \multirow{3}{*}{ Pocket money } & Pocket money & Motivation to learn \\
\cline { 2 - 4 } & Pearson Correlation & 1 & -155 \\
\cline { 2 - 4 } & Sig. (2-tailed) & & .415 \\
\cline { 2 - 4 } & $\mathrm{N}$ & 30 & 30 \\
\hline Motivation to learn & Pearson Correlation & -155 & 1 \\
\cline { 2 - 4 } & Sig. (2-tailed) & .415 & 30 \\
\cline { 2 - 4 } & $\mathrm{N}$ & 30 & \\
\hline
\end{tabular}

If the significance value is $<0.05$ then it is correlated and if the significance value is $>0.05$ then it is not correlated. Based on the table above, the significance value of the variables $\mathrm{X}$ and $\mathrm{Y}$ is 0.415 , meaning that these two variables have no relationship or correlation. While the correlation value is -0.155 . Referring to table 3.6 guidelines for providing interpretation of the correlation coefficient, the number is in the interval $0.00-0.199$, namely between variable X (monthly allowance) and variable Y (learning motivation) which has a very low correlation.Based on the table above, the correlation value shows a negative value in which the variables $\mathrm{X}$ and $\mathrm{Y}$ have an opposite relationship with the conclusion that if the value of the variable $\mathrm{X}$ (pocket money) is high, the value of the variable $\mathrm{Y}$ (learning motivation) will be low, and vice versa.

The results of the calculation of the coefficient of determination (r2) using computer assistance are as follows: Tabel 5. Test Of Determination

\begin{tabular}{|l|c|c|c|c|}
\hline \multicolumn{5}{|c|}{ Model Summary } \\
\hline Model & $\mathrm{R}$ & $\mathrm{R}$ Square & $\begin{array}{c}\text { Adjusted R } \\
\text { Square }\end{array}$ & $\begin{array}{c}\text { Std. Error of the } \\
\text { Estimate }\end{array}$ \\
\hline 1 & $155^{\mathrm{a}}$ & .024 & -.011 & 3.416 \\
\hline \multicolumn{7}{|l}{} \\
\hline
\end{tabular}

Based on the table of calculation results above, the value of the correlation / relationship ( $R$ ) is 0.155 . From the output, the coefficient of determination (R Square) is 0.024 which means that the relationship between variable $\mathrm{X}$ (pocket money) and variable $\mathrm{Y}$ (learning motivation) is $2.4 \%$ and the remaining $97.6 \%$ is influenced by other factors.

The results of the regression calculations using computer assistance are as follows:

Tabel 6. Calculation of the Regression Equation

ANOVA : 
International Journal of Social Science (IJSS)

Vol.1 Issue.5 February 2022, pp: 541-548

ISSN: 2798-3463 (Printed) | 2798-4079 (Online)

DOI: https://doi.org/10.53625/ijss.v1i5.869

\begin{tabular}{|l}
\hline \begin{tabular}{l|l|r|r|r|r|l|}
\hline \multicolumn{2}{|l|}{ Model } & Sum of Squares & df & Mean Square & F & Sig. \\
\hline \multirow{2}{*}{1} & Regression & 7.990 & 1 & 7.990 & .685 & .415 b \\
\cline { 2 - 7 } & Residual & 326,710 & 28 & 11,668 & & \\
\cline { 2 - 7 } & Total & 334,700 & 29 & & & \\
\hline
\end{tabular} \\
a. Dependent Variable: Learning Motivation \\
b. Predictors: (Constant), Pocket Money \\
\hline
\end{tabular}

The table above shows the Fcount of 0.685 . While Ftable with df $1=k-1(2-1=1)$ and df $2=30-2=28$ with an error rate of 5\%, the value of Ftable is 4.20. If Fcount > Ftable, then Ha is accepted and Ho is rejected, whereas if Fcount $<$ Ftable then Ha is rejected and Ho is accepted. Based on this comparison, Fcount $<$ Ftable, so it can be concluded that the variable $\mathrm{X}$ (monthly allowance) has no relationship to the variable $\mathrm{Y}$ (learning motivation).

The results of the calculation of correlation with computer aids are as follows:

Tabel 7. Output of Calculation of Correlation Coefficient

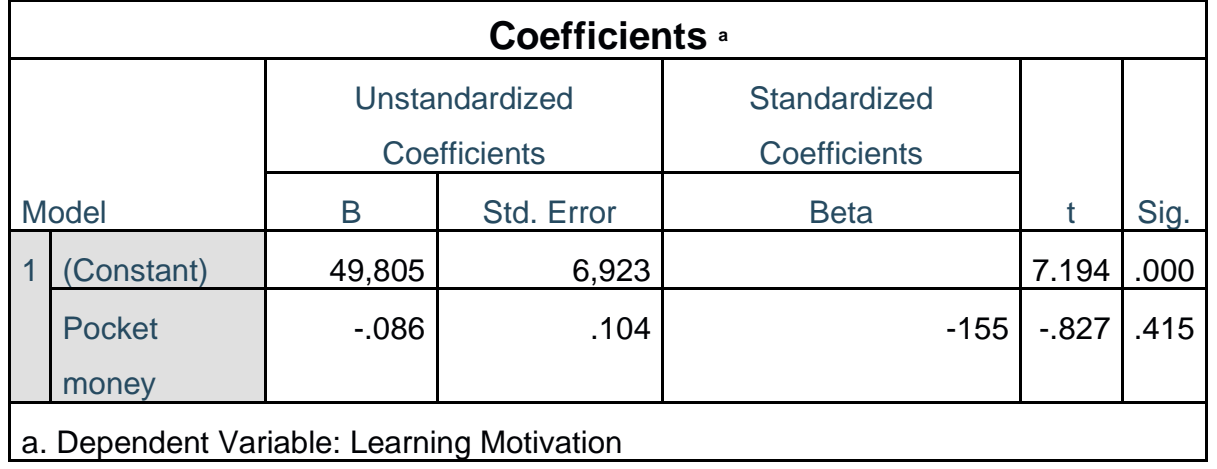

Based on the table above, in column B Constant (a) is 49.805 while the value of Trust (b) is -0.086 . So that the regression equation can be calculated as follows:

$\mathrm{Y}=\mathrm{a}+\mathrm{bX}$

$\mathrm{Y}=49.805+(-0.086) \mathrm{X}$

The equation can be translated:

The constant of 49.805 means that the constant value of the monthly allowance variable is 49.805 . The regression coefficient of $\mathrm{X}$ is -0.086 which means that for every $1 \%$ decrease in the value of learning motivation, the value of the monthly allowance decreases by -0.086 . The regression coefficient is negative, so it can be said that the direction of the relationship between $\mathrm{X}$ and $\mathrm{Y}$ is negative.

This is evidenced by the results of correlation analysis using Pearson's Correlations with the results of correlation analysis explaining the correlation value is -0.155 . Referring to table 3.6 guidelines for providing interpretation of the correlation coefficient, the number is in the interval $0.00-0.199$, namely between variable $\mathrm{X}$ (monthly allowance) and variable Y (learning motivation) which has a very low correlation. Based on table 4.15 the correlation value shows a negative value in which the variables $\mathrm{X}$ and $\mathrm{Y}$ have an opposite relationship with the conclusion that if the value of the variable $\mathrm{X}$ (pocket money) is high, then the value of the variable $\mathrm{Y}$ (learning motivation) will be low, and vice versa.

According to the results of other previous studies, namely by Iswahyuni stated that learning motivation significantly has an influence on learning achievement which is contained in the factors that influence learning motivation, one of which is the internal factor, namely aspirations which mean the existence of hopes and goals for success in learning. . From this research, it shows that there is a relationship equation, with this study as the results of the correlation and regression of this study is Fcount of 0.685 . While Ftable with df $1=\mathrm{k}-1(2-1=1)$ and df $2=30$ $-2=28$ with an error rate of $5 \%$, the value of Ftable is 4.20. If Fcount $>$ Ftable, then Ho is accepted and Ha is rejected, whereas if Fcount < Ftable then Ho is rejected and Ha is accepted. Based on this comparison, Fcount > Ftable, it can be concluded that the variable X (monthly allowance) has an influence on the variable Y (learning motivation).

If referring to the theory stated by Syaiful Bahri Djamarah in the forms of learning motivation, namely giving numbers and prizes, in this study students at the Al-Hidayah Islamic Boarding School did not need to give numbers in the form of a large nominal pocket money to motivate them in learning, as well as gifts that may often be 
associated with other nominal matters. In this case, it can be concluded that the students of Al-Hidayah Islamic Boarding School have physical and spiritual motivation, because the results of this study show negative results which can be concluded that monthly pocket money is not something that can motivate them in learning fiqh learning. If it is associated with other forms of learning motivation, it includes intrinsic motivation as stated by Sardiman AM (2012), namely that the motives that become active or function do not need to be stimulated from outside. In this aspect of learning, it is necessary to have the willingness or motive to learn on their own. On resultthe correlation/relationship (R) value is 0.155 . From the output, the coefficient of determination (R Square) is 0.024 which means that the relationship between variable $\mathrm{X}$ (pocket money) and variable $\mathrm{Y}$ (learning motivation) is $2.4 \%$ and the remaining $97.6 \%$ is influenced by other factors.

\section{CONCLUSION}

Based on the results of the research that has been described, regarding the relationship between monthly allowances and motivation to study fiqh learning in students at the Al-Hidayah Islamic Boarding School, Purwakarta, it can be concluded that In the results of the correlation analysis using Pearson's Correlations with the results of the correlation analysis, the correlation value is -0.155 . Referring to table 3.6 guidelines for providing interpretation of the correlation coefficient, the number is in the interval $0.00-0.199$, namely between variable $\mathrm{X}$ (monthly allowance) and variable Y (learning motivation) which has a very low correlation. Based on table 4.15 the correlation value shows a negative value in which the variables $\mathrm{X}$ and $\mathrm{Y}$ have an opposite relationship with the conclusion that if the value of the variable $\mathrm{X}$ (pocket money) is high, then the value of the variable $\mathrm{Y}$ (learning motivation) will be low, and vice versa. While the results of the correlation/relationship (R) value is 0.155 . From the output, the coefficient of determination ( $\mathrm{R}$ Square) is 0.024 which means that the relationship between variable $\mathrm{X}$ (pocket money) and variable Y (learning motivation) is $2.4 \%$ and the remaining $97.6 \%$ is influenced by other factors.

\section{REFERENCES}

[1] Soedarwani, "Pengaruh Model Pembimbingan Behavioristik, Motivasi Belajar dan Tingkat Ekonomi Orang Tua terhadap Kedisiplinan Siswa SMK Batik 2 Surakarta," Indones. Econ. Bus. Manag. Res., vol. 1, hal. 79-83, 2018.

[2] Dian Ika Puspitasari, "Kiat Wanita Karier Dalam Mendisiplinkan Anak Untuk Mengelola Uang Saku Di Perumahan Wonorejo Kecamatan Kedungjajang Kabupaten Lumajang," J. Ilm. Ilmu Pendidikan, Ilmu Ekon. dan Ilmu Sos., vol. 9, hal. 19-34, 2016.

[3] Bambang Widjajanta, Mengasah Kemampuan Ekonomi. Bandung: Citra Praya, 2007.

[4] Paul W. Lermitte, Agar Anak Pandai Mengelola Uang. Jakarta: PT Gramedia Pustaka Utama, 2004.

[5] Azmi Agustiar, "Manajemen Pengelolaan Keuangan Pesantren Modern Darul Ulum Banda Aceh dalam Perspektif Manajemen Syari'ah," UIN Ar-Raniry Banda Aceh, 2018.

[6] Imam Tabroni, Model Pendidikan Islam. Bandung: Cendikia Press, 2019.

[7] Aldila Septiana, "Aldila Septiana," in Model Literasi Keuangan Pondok Pesantren Madura, 2017, hal. 1-8.

[8] Sardiman, Interaksi dan Motivasi Belajar Mengajar, 12 ed. Jakarta: CV Rajawali, 2012.

[9] Syaiful Bahri Djamarah, Psikologi Belajar. Jakarta: Rineka Cipta, 2002.

[10] Sugiyono, Metode Penelitian Pendidikan. Bandung: Alfabeta, 2010.

[11] Suharsimi Arikunto, Prosedur Penelitian Suatu Pendekatan Praktik. Jakarta: Rhineka Cipta, 2010. 